\title{
Nocardiopsis quinghaiensis sp. nov., isolated from saline soil in China
}

\author{
Yi-Guang Chen, ${ }^{1}{ }^{2}+$ Xiao-Long Cui, ${ }^{1} \dagger$ Reiner M. Kroppenstedt, ${ }^{3}$ \\ Erko Stackebrandt, ${ }^{3}$ Meng-Liang Wen, ${ }^{1}$ Li-Hua Xu ${ }^{1}$ and Cheng-Lin Jiang ${ }^{1}$
}

Correspondence

Reiner M. Kroppenstedt kdt@dsmz.de

\author{
${ }^{1}$ Yunnan Institute of Microbiology, Yunnan University, Kunming, Yunnan 650091, People's Republic \\ of China \\ ${ }^{2}$ College of Bio-resources and Environmental Science, Jishou University, Jishou, Hunan 416000, \\ People's Republic of China \\ ${ }^{3} \mathrm{DSMZ}$ - Deutsche Sammlung von Mikroorganismen und Zellkulturen GmbH, Inhoffenstraße 7b, \\ D-38124 Braunschweig, Germany
}

\begin{abstract}
A previously unknown Gram-positive, obligately aerobic actinomycete, YIM 28A4 ${ }^{\top}$, was isolated from a sample of saline soil collected from the Qaidam Basin in Qinghai Province, north-west China, and was investigated using a polyphasic taxonomic approach. The strain grew well on most of the media tested, producing white to pale-yellow substrate mycelium, white aerial mycelium and straight to flexuous hyphae. The substrate mycelium was well developed and fragmented with age; the aerial mycelium produced long, straight spore chains. The spore chains were composed of non-motile, smooth-surfaced, rod-shaped spores. No diffusible pigments were produced on any of the media tested. The strain grew in the presence of $0-10 \%(\mathrm{w} / \mathrm{v}) \mathrm{NaCl}$ and at $\mathrm{pH}$ 6.0-8.0, with optimum growth occurring at $3 \%(w / v) ~ N a C l$ and $\mathrm{pH} 7.0$. It grew at $10-37{ }^{\circ} \mathrm{C}$, the optimum growth temperature being $28^{\circ} \mathrm{C}$. Whole-cell hydrolysates of strain YIM $28 \mathrm{~A} 4^{\top}$ contained meso-diaminopimelic acid and no diagnostic sugars. The predominant phospholipids were phosphatidylcholine, phosphatidylglycerol and diphosphatidylglycerol. The predominant menaquinones were MK-10, MK-10 $\left(\mathrm{H}_{2}\right), \mathrm{MK}-11$ and $\mathrm{MK}-11\left(\mathrm{H}_{2}\right)$. The major cellular fatty acids were iso- $C_{16: 0}$, anteiso- $C_{15: 0}$ and anteiso- $C_{17: 0}$. The DNA G+C content was $67.1 \mathrm{~mol} \%$. The morphological and chemotaxonomic characteristics of the isolate matched those described for Nocardiopsis species. A phylogenetic analysis based on 16S rRNA gene sequence comparisons confirmed that strain YIM $28 \mathrm{~A} 4^{\top}$ was a member of the genus Nocardiopsis and most closely related to the type strains Nocardiopsis aegyptia DSM $44442^{\top}$ and Nocardiopsis halotolerans DSM $44410^{\top}$, showing 98.1 and $97.8 \% 16 \mathrm{~S}$ rRNA gene sequence similarity, respectively. Strain YIM 28A $4^{\top}$ can be differentiated from these type strains by using phenotypic, phylogenetic and DNA-DNA hybridization data. On the basis of the polyphasic evidence, strain YIM $28 A 4^{\top}$ represents a novel species of the genus Nocardiopsis, for which the name Nocardiopsis

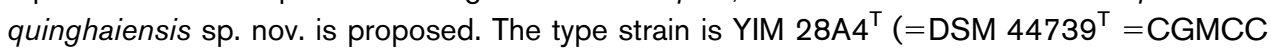
$4.3494^{\mathrm{T}}$ ).
\end{abstract}

The genus Nocardiopsis was first described by Meyer (1976) and currently comprises 24 species with validly published names (Meyer, 1976; Grund \& Kroppenstedt, 1990; Yassin et al., 1993, 1997; Al-Tai \& Ruan, 1994; Chun et al., 2000; Evtushenko et al., 2000; Peltola et al., 2001; Al-Zarban et al., 2002; Kämpfer et al., 2002; Schippers et al., 2002; Li et al., 2003, 2004; Hozzein et al., 2004; Sabry et al., 2004). During a recent study on the diversity of microbiological

†These authors equally contributed to this work.

The GenBank/EMBL/DDBJ accession number for the 16S rRNA gene sequence of strain YIM 28A4 ${ }^{\top}$ is EF597511. communities in the soils of Qinghai Province (north-west China), a Nocardiopsis-like strain, designated YIM $28 \mathrm{~A}^{\mathrm{T}}$, was isolated from a sample of saline soil collected from the Chaidam Basin (Cui et al., 2004; Schumann et al., 2004; Li et al., 2005a, b, c, d, 2006; Zhang et al., 2005, 2007). On the basis of the results of this polyphasic taxonomic study, it is proposed that strain YIM $28 \mathrm{~A} 4^{\mathrm{T}}$ represents a novel species of the genus Nocardiopsis.

Strain YIM $28 \mathrm{~A} 4^{\mathrm{T}}$ was isolated from a sample of saline soil by plating $1: 10$ serial dilutions of the sample on marine agar 2216 (Difco) at $28{ }^{\circ} \mathrm{C}$ for 2 weeks. The strain was maintained both on a marine agar 2216 slant at $4{ }^{\circ} \mathrm{C}$ and at 
$-80{ }^{\circ} \mathrm{C}$ in marine broth (Difco) supplemented with $20 \%$ (v/v) glycerol. Two type strains of the genus Nocardiopsis, Nocardiopsis aegyptia DSM $44442^{\mathrm{T}}$ and Nocardiopsis halotolerans DSM $44410^{\mathrm{T}}$, were used in some parallel tests. Morphological characteristics were observed by using light microscopy (BH 2; Olympus) and scanning electron microscopy (JSM5600LV; JEOL) after 2 and 4 week periods of growth on yeast extract-malt extract agar (ISP 2; Shirling \& Gottlieb, 1966) supplemented with $3 \%(\mathrm{w} / \mathrm{v})$ $\mathrm{NaCl}$. Anaerobic growth was determined using a GasPak Anaerobic System pot (BBL) according to the manufacturer's instructions. Cultural characteristics were determined after 2-4 weeks by using the methods applied in the International Streptomyces Project (Shirling \& Gottlieb, 1966). All media were supplemented with $3 \%(w / v) ~ N a C l$ ( $\mathrm{pH}$ 7.0). The colours of both substrate and aerial mycelia and any soluble pigments produced were determined by comparison with chips from the colour charts of the InterSociety Color Council - National Bureau of Standards (Kelly, 1964).

Strain YIM 28A4 $4^{\mathrm{T}}$ showed the macroscopic and microscopic appearance typical of most species of the genus Nocardiopsis (Meyer, 1976, 1994). The strain was Grampositive and obligately aerobic. The substrate mycelium was white to pale-yellow, well developed and fragmented with age. The white aerial mycelium was well developed on most of the media tested (Table 1) and the spore chains were long, containing rod-shaped, smooth-surfaced, nonmotile spores. Hyphae from the aerial mycelium were straight to flexuous (Fig. 1). No diffusible pigments were produced on any of the media tested.

Genomic DNA extraction, PCR-mediated amplification of the 16S rRNA gene, purification of PCR products and electrophoresis of sequencing reactions were performed as described previously (Cui et al., 2001). The resulting $16 \mathrm{~S}$ rRNA gene sequence was compared with sequences obtained from databases, to find the most closely related species. A phylogenetic analysis was performed using the software packages PHYLIP (Felsenstein, 1993) and MEGA, version 3.1 (Kumar et al., 2004), after multiple alignment of the data by CLUSTAL_X (Thompson et al., 1997).

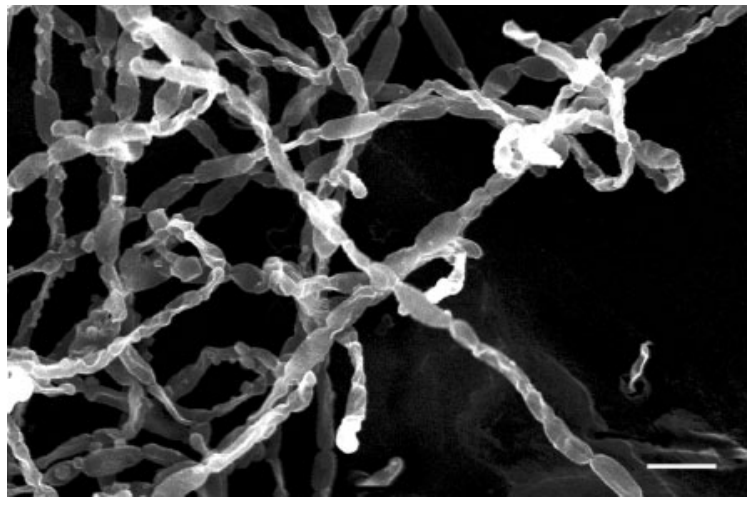

Fig. 1. Scanning electron micrograph of strain YIM $28 A 4^{\top}$ grown on Czapek agar supplemented with $3 \%(\mathrm{w} / \mathrm{v}) \mathrm{NaCl}$ at $28{ }^{\circ} \mathrm{C}$ for 28 days. Bar, $2 \mu \mathrm{m}$.

Distances were calculated using distance options according to Kimura's two-parameter model (Kimura, 1980) and clustering was performed with the neighbour-joining method (Saitou \& Nei, 1987). A maximum-parsimony (Kluge \& Farris, 1969) phylogenetic tree (not shown) was generated using the treeing algorithms contained in the PHYLIP package (Felsenstein, 1993). Bootstrap analysis was used to evaluate the tree topology of the neighbour-joining data by means of 1000 resamplings (Felsenstein, 1985).

The almost-complete 16S rRNA gene sequence (1384 bp) of strain YIM $28 \mathrm{~A} 4^{\mathrm{T}}$ was determined. A preliminary comparison of the sequence against the GenBank database indicated that the isolate was closely related to the members of the genus Nocardiopsis and that it was phylogenetically most closely related to $N$. aegyptia DSM $44442^{\mathrm{T}}$ and $N$. halotolerans DSM $44410^{\mathrm{T}}$, with sequence similarities of 98.1 and $97.8 \%$, respectively. The other closest phylogenetic neighbours of strain YIM $28 \mathrm{~A} 4^{\mathrm{T}}$ (sequence similarity value $>97 \%$ ) were Nocardiopsis dassonvillei subsp. dassonvillei DSM $43111^{\mathrm{T}} \quad(97.6 \%$ sequence similarity), Nocardiopsis umidischolae DSM $44362^{\mathrm{T}}(97.4 \%)$, Nocardiopsis lucentensis DSM $44048^{\mathrm{T}}$ (97.3\%), Nocardiopsis alba DSM $43377^{\mathrm{T}}(97.2 \%)$,

Table 1. Cultural characteristics of strain YIM $28 \mathrm{~A} 4^{\top}$

All media were adjusted to $\mathrm{pH} 7.0$ and supplemented with $3 \%(\mathrm{w} / \mathrm{v}) \mathrm{NaCl}$. ISP, International Streptomyces

Project (Shirling \& Gottlieb, 1966). The strain formed white aerial mycelium on all media tested.

\begin{tabular}{|llc|}
\hline Medium & Growth & Substrate mycelium \\
\hline Yeast extract-malt extract agar (ISP 2) & Good & White \\
Oatmeal agar (ISP 3) & Good & White \\
Inorganic salts-starch agar (ISP 4) & Moderate & White \\
Glycerol-asparagine agar (ISP 5) & Poor & White \\
Peptone-yeast extract-iron agar (ISP 6) & Poor & Pale yellow \\
Czapek agar & Abundant & White \\
Potato extract agar & Good & Pale yellow \\
\hline
\end{tabular}


Nocardiopsis tropica DSM $44381^{\mathrm{T}} \quad(97.1 \%)$ and Nocardiopsis salina YIM $90010^{\mathrm{T}}$ (97.1\%). These sequence similarity values are lower than those found for some other individual pairs of Nocardiopsis species, as discussed previously (Al-Zarban et al., 2002; Schippers et al., 2002; Hozzein et al., 2004; Sabry et al., 2004). In the neighbourjoining phylogenetic tree for Nocardiopsis species (Fig. 2), strain YIM $28 \mathrm{~A}^{\mathrm{T}}$ and $N$. halotolerans DSM $44410^{\mathrm{T}}$ formed a sub-branch with low bootstrap support $(66 \%)$. To establish the precise taxonomic position of YIM $28 \mathrm{~A} 4^{\mathrm{T}}$, DNA-DNA hybridization studies were performed, using the optical renaturation method (De Ley et al., 1970; Huß et al., 1983; Jahnke, 1992), between the novel strain and the type strains $N$. aegyptia DSM $44442^{\mathrm{T}}$ and $N$. halotolerans DSM $44410^{\mathrm{T}}$. The DNA-DNA relatedness between strain YIM $28 \mathrm{~A} 4^{\mathrm{T}}$ and $N$. aegyptia DSM $44442^{\mathrm{T}}$ was $20.0 \%$, while the value for $N$. halotolerans DSM $44410^{\mathrm{T}}$ was $24.5 \%$. These values are far below the threshold value of about $70 \%$ recommended by Wayne et al. (1987) for the assignment of strains to the same species. On the basis of phylogenetic analysis and the DNA-DNA hybridization data, a clear differentiation of strain YIM $28 \mathrm{~A}^{\mathrm{T}}$ from $N$. aegyptia DSM $44442^{\mathrm{T}}$ and $N$. halotolerans DSM $44410^{\mathrm{T}}$ was possible.

DNA for the determination of the $\mathrm{G}+\mathrm{C}$ content was isolated according to Hopwood et al. (1985). The G+C content, determined using the thermal denaturation

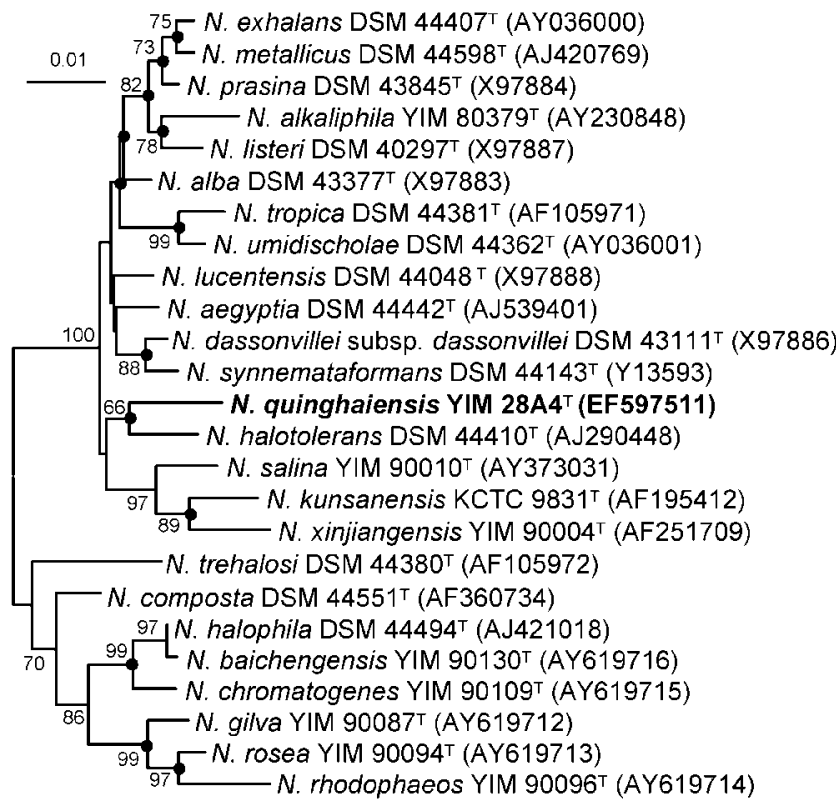

Fig. 2. Neighbour-joining phylogenetic dendrogram, based on 16S rRNA gene sequence analysis, showing the phylogenetic position of strain YIM $28 \mathrm{~A} 4^{\top}$ among members of the genus Nocardiopsis. Filled circles indicate branches that were also found with the maximum-parsimony (Kluge \& Farris, 1969) algorithm. Bootstrap values $(>50 \%)$ are indicated at the relevant branching points. Bar, 1 substitution per 100 nucleotides. method of Mandel \& Marmur (1968) with a Shimadzu UV-visible spectrophotometer (UV1601), was $67.1 \mathrm{~mol} \%$.

The media and procedures used to determine physiological and biochemical features and to identify the carbon sources utilized were those described by Kroppenstedt \& Evtushenko (2006), Shirling \& Gottlieb (1966) and Williams et al. (1989). Unless otherwise indicated, all tests were carried out with $3 \% \mathrm{NaCl}(\mathrm{w} / \mathrm{v})$ at $\mathrm{pH} 7.0$ with incubation at $28{ }^{\circ} \mathrm{C}$. The results are listed in Table 2 and in the species description.

Biomass for chemical and systematic molecular studies was obtained from cultures grown in trypticase soy broth (BBL) at $28{ }^{\circ} \mathrm{C}$ for 3 days on a rotary shaker (about 200 r.p.m.). Cells were harvested by centrifugation and washed twice with distilled water. Analyses of the amino acids and sugars in whole-cell hydrolysates were performed according to the procedures described by Staneck \& Roberts (1974). Polar lipids were extracted, examined using two-dimensional TLC and identified using published procedures (Minnikin et al., 1984). Menaquinones were isolated using the methods of Minnikin et al. (1984) and then separated by HPLC (Kroppenstedt, 1982, 1985). Cellular fatty acids were analysed according to Kämpfer \& Kroppenstedt (1996) with cells grown on trypticase soy agar (BBL) for 4 days at $28{ }^{\circ} \mathrm{C}$.

Chemotaxonomic data for YIM $28 \mathrm{~A} 4^{\mathrm{T}}$ were consistent with the assignment of the strain to the genus Nocardiopsis (Meyer, 1976; Kroppenstedt \& Evtushenko, 2006). Wholecell hydrolysates contained meso-diaminopimelic acid as the only diamino acid of the peptidoglycan. Diagnostic sugars were not found. The polar lipid pattern was composed of phosphatidylcholine, phosphatidylglycerol and diphosphatidylglycerol. The major menaquinones were MK-10 (29.7\%), MK-10( $\left.\mathrm{H}_{2}\right)(23.3 \%)$, MK-11( $\left.\mathrm{H}_{2}\right)(17.7 \%)$, MK$11(15.2 \%)$ and MK-9 $\left(\mathrm{H}_{4}\right)(5.2 \%)$. Traces of MK-9( $\left.\mathrm{H}_{6}\right)$ and MK-12 were also found. The fatty acid profiles of strain YIM $28 \mathrm{~A} 4^{\mathrm{T}}, N$. aegyptia DSM $44442^{\mathrm{T}}$ and $N$. halotolerans DSM $44410^{\mathrm{T}}$ are given in Table 3. The major cellular fatty acids of strain YIM $28 \mathrm{~A}^{\mathrm{T}}$ were iso- $\mathrm{C}_{16: 0}(30 \%)$, anteiso$\mathrm{C}_{15: 0}(15 \%)$ and anteiso- $\mathrm{C}_{17: 0}(10 \%)$.

Phenotypically, the properties of strain YIM $28 \mathrm{~A} 4^{\mathrm{T}}$ supported its placement in the genus Nocardiopsis (Meyer, 1976; Kroppenstedt \& Evtushenko, 2006). However, the novel strain could be differentiated from its closest relatives by using a combination of morphological, physiological and chemotaxonomic data. A comparison of selected characteristics of strain YIM $28 \mathrm{~A} 4^{\mathrm{T}}$ with those of its closest relatives, $N$. aegyptia DSM $44442^{\mathrm{T}}$ and $N$. halotolerans DSM $44410^{\mathrm{T}}$, is presented in Table 2. Strain YIM $28 \mathrm{~A} 4^{\mathrm{T}}$ differed from N. aegyptia DSM $44442^{\mathrm{T}}$ and $N$. halotolerans DSM $44410^{\mathrm{T}}$ in terms of colony colour, physiological test results and chemotaxonomy. Strain YIM $28 \mathrm{~A} 4^{\mathrm{T}}$ produced white aerial mycelium and paleyellow substrate mycelium, whereas DSM $44442^{\mathrm{T}}$ and DSM $44410^{\mathrm{T}}$ produce beige or dirty-white aerial mycelium and brown or beige-brown substrate mycelium, respectively. In 
Table 2. Characteristics that distinguish strain $\mathrm{YIM} 28 \mathrm{~A} 4^{\top}$ from its closest phylogenetic relatives

Data for N. aegyptia DSM $44442^{\mathrm{T}}$ and N. halotolerans DSM $44410^{\mathrm{T}}$ were taken from Sabry et al. (2004) and Al-Zarban et al. (2002), respectively, unless indicated. + , Positive; -, negative; ND, no data. All strains were positive for the hydrolysis of casein and negative for $\mathrm{H}_{2} \mathrm{~S}$ and $\mathrm{melanin}$ production and urease activity (data from our study).

\begin{tabular}{|c|c|c|c|}
\hline Characteristic & Strain YIM $28 \mathrm{~A} 4^{\mathrm{T}}$ & N. aegyptia DSM $44442^{\mathrm{T}}$ & N. halotolerans DSM $44410^{\mathrm{T}}$ \\
\hline \multicolumn{4}{|l|}{ Pigmentation of mycelium } \\
\hline Aerial mycelium & White & Beige to light yellow & Dirty white to yellow-grey \\
\hline Substrate mycelium & White to pale yellow & Brown & Beige to brown \\
\hline \multicolumn{4}{|l|}{$\mathrm{NaCl}$ concentration for growth $(\%, \mathrm{w} / \mathrm{v})$} \\
\hline Range & $0-10$ & $0-5^{*}$ & $0-15$ \\
\hline Optimum & 3 & $\mathrm{ND}$ & 10 \\
\hline \multicolumn{4}{|l|}{ Temperature for growth $\left({ }^{\circ} \mathrm{C}\right)$} \\
\hline Range & $10-37$ & $10-40^{*}$ & $10-35$ \\
\hline Optimum & 28 & 28 & 28 \\
\hline \multicolumn{4}{|l|}{ Hydrolysis of: $\dagger$} \\
\hline Starch & + & - & - \\
\hline Gelatin & - & + & + \\
\hline Tween 80 & + & + & - \\
\hline Nitrate reduction $\dagger$ & - & + & - \\
\hline \multicolumn{4}{|l|}{ Utilization of: $\ddagger$} \\
\hline L-Arabinose & + & + & - \\
\hline Galactose & - & + & + \\
\hline D-Lactose & - & + & $\mathrm{ND} /-\dagger$ \\
\hline Melibiose & - & $\mathrm{ND} /-\dagger$ & + \\
\hline L-Rhamnose & - & + & $\mathrm{ND} /-\dagger$ \\
\hline D-Xylose & - & + & - \\
\hline \multicolumn{4}{|l|}{ Fatty acid profile (\%) } \\
\hline Major fatty acids & $\begin{array}{l}\text { iso- } \mathrm{C}_{16: 0}(30) \text {; } \\
\text { anteiso- } \mathrm{C}_{15: 0}(15)\end{array}$ & $\begin{array}{l}\text { iso- } \mathrm{C}_{16: 0}(19) \text {; } \\
\text { anteiso- } \mathrm{C}_{17: 0}(18)\end{array}$ & $\begin{array}{l}\text { iso- } \mathrm{C}_{16: 0}(23) ; \\
\text { anteiso- } \mathrm{C}_{17: 0}(18)\end{array}$ \\
\hline Unbranched saturated fatty acids & 12 & 13 & 10 \\
\hline 10-Methyl-branched fatty acids & 9 & 16 & 4 \\
\hline Unsaturated fatty acids & 7 & 11 & 17 \\
\hline Major menaquinones & $\begin{array}{c}\text { MK-10, } \mathrm{MK}-10\left(\mathrm{H}_{2}\right), \text { MK-11, } \\
\left.\text { MK-11( } \mathrm{H}_{2}\right)\end{array}$ & $\begin{array}{l}\text { MK-10 }\left(\mathrm{H}_{6}\right), \text { MK-10 }\left(\mathrm{H}_{8}\right), \\
\text { MK-10 }\left(\mathrm{H}_{4}\right), \text { MK-10 }\left(\mathrm{H}_{2}\right)\end{array}$ & $\begin{array}{l}\text { MK-10, MK-10 }\left(\mathrm{H}_{2}\right), \\
\text { MK-10 }\left(\mathrm{H}_{4}\right), \text { MK-11 }\end{array}$ \\
\hline Phospholipids $\S$ & PC, PG, DPG & PC, PI, PG, PME, DPG & PC, PI, PG, PME, DPG \\
\hline DNA G $+C$ content $(\mathrm{mol} \%)$ & 67.1 & $\mathrm{ND}$ & 68.0 \\
\hline
\end{tabular}

${ }^{*}$. aegyptia DSM $44442^{\mathrm{T}}$ grew at $10-40{ }^{\circ} \mathrm{C}$ and in $5 \% \mathrm{NaCl}$, but not at $45{ }^{\circ} \mathrm{C}$ or with $10 \% \mathrm{NaCl}$ (Sabry et al., 2004).

$\dagger$ Our results.

$\ddagger$ Unless otherwise indicated, results of these tests for strains N. aegyptia DSM $44442^{\mathrm{T}}$ and N. halotolerans DSM $44410^{\mathrm{T}}$ were confirmed in parallel tests with strain YIM $28 \mathrm{~A} 4^{\mathrm{T}}$ under identical conditions.

§DPG, Diphosphatidylglycerol; PC, phosphatidylcholine; PG, phosphatidylglycerol; PI, phosphatidylinositol; PME, phosphatidylmethylethanolamine.

contrast to those two strains, YIM $28 \mathrm{~A} 4^{\mathrm{T}}$ was able to hydrolyse starch but not gelatin. It could utilize L-arabinose as a sole source of carbon but failed to grow on galactose, D-lactose, melibiose, L-rhamnose or D-xylose. All of these sugars (except melibiose) could be assimilated by DSM $44442^{\mathrm{T}}$, whereas DSM $44410^{\mathrm{T}}$ could only grow on galactose and melibiose (Table 2). YIM 28A4 $4^{\mathrm{T}}$ showed a typical Nocardiopsis fatty acid profile containing a relatively large amount of 14-methyl hexadecanoic acid (anteiso- $\mathrm{C}_{17: 0}$ ) in combination with 10-methyl octadecanoic acid (tuberculostearic acid; 10-methyl $\mathrm{C}_{18: 0}$ ). YIM 28A4 ${ }^{\mathrm{T}}$ synthesized relatively small amounts of unsaturated fatty acids in comparison with DSM $44442^{\mathrm{T}}$ and DSM $44410^{\mathrm{T}}$ (Tables 2 and 3). The salt tolerance of the novel strain also differed with respect to those two strains: YIM $28 \mathrm{~A}^{\mathrm{T}}$ was able to grow at $\mathrm{NaCl}$ concentrations up to $10 \%(\mathrm{w} / \mathrm{v})$, DSM $44442^{\mathrm{T}}$ can grow only at $5 \% \mathrm{NaCl}(\mathrm{w} / \mathrm{v})$ and DSM $44410^{\mathrm{T}}$ grows well at $15 \% \mathrm{NaCl}(\mathrm{w} / \mathrm{v})$.

Thus, on the basis of the phylogenetic analysis, phenotypic distinctiveness (Table 2) and DNA-DNA relatedness data presented above, strain YIM $28 \mathrm{~A} 4^{\mathrm{T}}$ represents a novel species of the genus Nocardiopsis, for which the name Nocardiopsis quinghaiensis sp. nov. is proposed. 
Table 3. Fatty acid compositions (\%) of strain YIM $28 \mathrm{~A} 4^{\top}$ and its closest phylogenetic relatives

Strains: 1, YIM 28A4 ${ }^{\mathrm{T}} ; 2$, N. aegyptia DSM $44442^{\mathrm{T}}$ (data from Sabry et al., 2004); 3, N. halotolerans DSM $44410^{\mathrm{T}}$ (data from this study). -, Not present. Trace components in the fatty acid composition of strain YIM $28 \mathrm{~A}^{\mathrm{T}}{ }^{\text {were iso- }} \mathrm{C}_{12: 0}(0.20 \%)$, iso- $\mathrm{C}_{13: 0}(0.25 \%)$, anteiso- $\mathrm{C}_{13: 0}$ $(0.47 \%), \mathrm{C}_{14: 0}(0.27 \%)$ and $\mathrm{C}_{15: 0}(0.75 \%)$. A small amount of anteiso- $\mathrm{C}_{13: 0}(0.57 \%)$ was also found to be present in $\mathrm{N}$. halotolerans DSM $44410^{\mathrm{T}}$. Trace components $(<1 \%$ of total $)$ in the fatty acid composition of N. aegyptia DSM $44442^{\mathrm{T}}$ were not listed (Sabry et al., 2004).

\begin{tabular}{|c|c|c|c|}
\hline Fatty acid & 1 & 2 & 3 \\
\hline \multicolumn{4}{|c|}{ Unbranched saturated fatty acids } \\
\hline $\mathrm{C}_{16: 0}$ & 3.66 & 4.21 & 3.21 \\
\hline $\mathrm{C}_{17: 0}$ & 2.83 & 1.72 & 3.08 \\
\hline $\mathrm{C}_{18: 0}$ & 4.45 & 7.32 & 3.46 \\
\hline \multicolumn{4}{|c|}{ Unsaturated fatty acids } \\
\hline $\mathrm{C}_{16: 1}$ cis-9 & - & 1.10 & 1.33 \\
\hline $\mathrm{C}_{17: 1}$ cis-9 & 2.65 & 1.72 & 6.78 \\
\hline $\mathrm{C}_{18: 1}$ cis-9 & 4.57 & 7.76 & 8.52 \\
\hline \multicolumn{4}{|c|}{ Terminally branched fatty acids } \\
\hline iso- $\mathrm{C}_{14: 0}$ & 5.58 & 12.12 & 2.40 \\
\hline iso- $\mathrm{C}_{15: 0}$ & 2.59 & 1.70 & 3.38 \\
\hline anteiso- $\mathrm{C}_{15: 0}$ & 14.63 & 6.49 & 16.69 \\
\hline iso- $\mathrm{C}_{16: 0}$ & 30.02 & 19.14 & 23.30 \\
\hline iso- $\mathrm{C}_{17: 0}$ & 2.22 & 5.10 & 4.23 \\
\hline anteiso- $\mathrm{C}_{17: 0}$ & 9.99 & 17.85 & 18.12 \\
\hline anteiso- $\mathrm{C}_{17: 1}$ cis-9 & - & 1.35 & - \\
\hline iso- $\mathrm{C}_{18: 0}$ & 1.40 & 3.16 & 1.34 \\
\hline \multicolumn{4}{|c|}{ 10-Methyl-branched fatty acids } \\
\hline 10-Methyl $C_{16: 0}$ & 1.75 & 1.50 & - \\
\hline 10-Methyl $\mathrm{C}_{17: 0}$ & 2.78 & 2.58 & 1.61 \\
\hline 10-Methyl $C_{18: 0}$ & 4.51 & 12.19 & 1.32 \\
\hline
\end{tabular}

\section{Description of Nocardiopsis quinghaiensis sp. nov.}

Nocardiopsis quinghaiensis (quing.hai.en'sis. N.L. fem. adj. quinghaiensis pertaining to Qinghai, a province of China in which the sample was collected).

Gram-positive, obligately aerobic, non-motile, catalasepositive nocardioform actinomycete that forms white aerial mycelium. The colour of the substrate mycelium is white to pale yellow. Diffusible pigments are not produced. Substrate hyphae are well developed and fragment with age. Long spore chains are borne on aerial hyphae. Spores are rod-shaped, smooth and non-motile. Optimal growth occurs on marine agar 2216 and Czapek agar with $3 \%$ (w/v) $\mathrm{NaCl}$ at $28{ }^{\circ} \mathrm{C}$ and $\mathrm{pH}$ 7.0. The temperature, $\mathrm{pH}$ and $\mathrm{NaCl}$ concentration ranges for growth are $10-37^{\circ} \mathrm{C}$, $\mathrm{pH} 6.0-8.0$ and $0-10 \%$. Positive in tests for hydrolysis of casein, chitin, starch, Tween 20 and Tween 80 , but negative for hydrolysis of cellulose and gelatin. Nitrate is not reduced to nitrite. $\mathrm{H}_{2} \mathrm{~S}$, melanin and urease are not produced. L-Arabinose, cellobiose, citrate, D-fructose, Dglucose, glycerol, myo-inositol, D-mannitol, D-mannose, raffinose, D-ribose, sucrose, starch and trehalose are used as sole carbon and energy sources, whereas acetate, adonitol, D-galactose, D-lactose, maltose, melibiose, D-rhamnose, salicin, D-sorbitol, D-xylitol and D-xylose cannot be used for growth. L-Alanine, L-asparagine, L-glycine, L-histidine, hydroxy-L-proline, L-methionine, L-proline, L-threonine and L-tyrosine can be utilized as sole nitrogen sources, whereas adenine, L-arginine, L-cystine, glutamic acid, Llysine, phenylalanine, L-tryptophan and L-valine cannot. Whole-cell hydrolysates contain meso-diaminopimelic acid and no diagnostic sugars. The polar lipids comprise phosphatidylcholine, phosphatidylglycerol and diphosphatidylglycerol. The major menaquinones are MK-10 $(29.7 \%)$, MK-10( $\left.\mathrm{H}_{2}\right) \quad(23.3 \%), \quad \mathrm{MK}-11\left(\mathrm{H}_{2}\right) \quad(17.7 \%)$, MK-11 (15.2\%) and MK-9( $\left.\mathrm{H}_{4}\right)(5.2 \%)$. The major cellular fatty acids are iso- $\mathrm{C}_{16: 0}(30.0 \%)$, anteiso- $\mathrm{C}_{15: 0}(14.6 \%)$, anteiso- $\mathrm{C}_{17: 0}(10.0 \%)$, iso- $\mathrm{C}_{14: 0}(5.9 \%)$ and $\mathrm{C}_{18: 1} \omega 9 c$ $(4.6 \%)$. The DNA G + C content is $67.1 \mathrm{~mol} \%$.

The type strain, YIM $28 \mathrm{~A} 4^{\mathrm{T}}\left(=\mathrm{DSM} 44739^{\mathrm{T}}=\mathrm{CGMCC}\right.$ $4.3494^{\mathrm{T}}$ ), was isolated from a sample of saline soil collected from the Qaidam Basin, Qinghai Province, north-west China.

\section{Acknowledgements}

This work was supported by grants from the National Natural Science Foundation of China (30460004, 30660004, 30360004, 30560001), SRF for ROCS (SEM), the Yunnan Provincial Sciences and Technology Department (2005PY01-1, 2004C0002Z, 2006C0006M) and the National Basic Research Program of China ( 973 program, no. 2004CB719601). We are grateful to Gabi Pötter and Li-Xia Duan for their excellent technical assistance.

\section{References}

Al-Tai, A. M. \& Ruan, J. S. (1994). Nocardiopsis halophila sp. nov., a new halophilic actinomycete isolated from soil. Int J Syst Bacteriol 44, 474-478.

Al-Zarban, S. S., Abbas, I., Al-Musallam, A. A., Steiner, U., Stackebrandt, E. \& Kroppenstedt, R. M. (2002). Nocardiopsis halotolerans sp. nov., isolated from salt marsh soil in Kuwait. Int $J$ Syst Evol Microbiol 52, 525-529.

Chun, J., Bae, K. S., Moon, E. Y., Jung, S.-O., Lee, H. K. \& Kim, S.-J. (2000). Nocardiopsis kunsanensis sp. nov., a moderately halophilic actinomycete isolated from a saltern. Int J Syst Evol Microbiol 50, 1909-1913.

Cui, X.-L., Mao, P.-H., Zeng, M., Li, W.-J., Zhang, L.-P., Xu, L.-H. \& Jiang, C.-L. (2001). Streptomonospora salina gen. nov., sp. nov., a new member of the family Nocardiopsaceae. Int J Syst Evol Microbiol 51, 357-363.

Cui, X.-L., Schumann, P., Stackebrandt, E., Kroppenstedt, R. M., Pukall, R., Xu, L.-H., Rohde, M. \& Jiang, C.-L. (2004). Myceligenerans xiligouense gen. nov., sp. nov., a novel hyphae-forming member of the family Promicromonosporaceae. Int J Syst Evol Microbiol 54, 1287-1293.

De Ley, J., Cattoir, H. \& Reynaerts, A. (1970). The quantitative measurement of DNA hybridization from renaturation rates. Eur $J$ Biochem 12, 133-142.

Evtushenko, L. I., Taran, V. V., Akimov, V. N., Kroppenstedt, R. M., Tiedje, J. M. \& Stackebrandt, E. (2000). Nocardiopsis tropica sp. nov., 
Nocardiopsis trehalosi sp. nov., nom. rev. and Nocardiopsis dassonvillei subsp. albirubida subsp. nov., comb. nov. Int J Syst Evol Microbiol 50, 73-81.

Felsenstein, J. (1985). Confidence limits on phylogenies: an approach using the bootstrap. Evolution 39, 783-791.

Felsenstein, J. (1993). PHYLIP (phylogeny inference package), version 3.5c. Distributed by the author. Department of Genome Sciences, University of Washington, Seattle, USA.

Grund, E. \& Kroppenstedt, R. M. (1990). Chemotaxonomy and numerical taxonomy of the genus Nocardiopsis Meyer 1976. Int J Syst Bacteriol 40, 5-11.

Hopwood, D. A., Bibb, M. J., Chater, K. F., Kieser, T., Bruton, C. J., Kieser, H. M., Lydiate, D. J., Smith, C. P. \& Ward, J. M. (1985). Preparation of chromosomal, plasmid and phage DNA. In Genetic Manipulation of Streptomyces: a Laboratory Manual, pp. 79-80. Norwich: F. Crowe \& Sons.

Hozzein, W. N., Li, W. J., Ali, M. I. A., Hammouda, O., Mousa, A. S., Xu, L. H. \& Jiang, C. L. (2004). Nocardiopsis alkaliphila sp. nov., a novel alkaliphilic actinomycete isolated from desert soil in Egypt. Int J Syst Evol Microbiol 54, 247-252.

Huß, V. A. R., Festl, H. \& Schleifer, K. H. (1983). Studies on the spectrophotometric determination of DNA hybridization from renaturation rates. Syst Appl Microbiol 4, 184-192.

Jahnke, K. D. (1992). BASIC computer program for evaluation of spectroscopic DNA renaturation data from Gilford System 2600 spectrophotometer on a PC/XT/AT type personal computer. J Microbiol Methods 15, 61-73.

Kämpfer, P. \& Kroppenstedt, R. M. (1996). Numerical analysis of fatty acid patterns of coryneform bacteria and related taxa. Can J Microbiol 42, 989-1005.

Kämpfer, P., Busse, H.-J. \& Rainey, F. A. (2002). Nocardiopsis compostus sp. nov., from the atmosphere of a composting facility. Int $J$ Syst Evol Microbiol 52, 621-627.

Kelly, K. L. (1964). Inter-Society Color Council - National Bureau of Standards Color Name Charts Illustrated with Centroid Colors. Washington, DC: US Government Printing Office.

Kimura, M. (1980). A simple method for estimating evolutionary rates of base substitutions through comparative studies of nucleotide sequences. J Mol Evol 16, 111-120.

Kluge, A. G. \& Farris, F. S. (1969). Quantitative phyletics and the evolution of anurans. Syst Zool 18, 1-32.

Kroppenstedt, R. M. (1982). Separation of bacterial menaquinones by HPLC using reverse phase (RP18) and a silver loaded ion exchanger. J Liq Chromatogr 5, 2359-2367.

Kroppenstedt, R. M. (1985). Fatty acid and menaquinone analysis of actinomycetes and related organisms. In Chemical Methods in Bacterial Systematics (Society for Applied Bacteriology Technical Series vol. 20), pp. 173-199. Edited by M. Goodfellow \& D. E. Minnikin. New York: Academic Press.

Kroppenstedt, R. M. \& Evtushenko, L. I. (2006). The family Nocardiopsaceae. In The Prokaryotes: a Handbook on the Biology of Bacteria, 3rd edn, vol. 3, pp. 754-795. Edited by M. Dworkin, S. Falkow, E. Rosenberg, K. H. Schleifer \& E. Stackebrandt. New York: Springer.

Kumar, S., Tamura, K. \& Nei, M. (2004). MEGA3: integrated software for molecular evolutionary genetics analysis and sequence alignment. Brief Bioinform 5, 150-163.

Li, M.-G., Li, W.-J., Xu, P., Cui, X.-L., Xu, L.-H. \& Jiang, C.-L. (2003). Nocardiopsis xinjiangensis sp. nov., a halophilic actinomycete isolated from saline soil sample in China. Int J Syst Evol Microbiol 53, 317-321.

Li, W.-J., Tang, S.-K., Park, D. J., Wang, D., Lee, J. C., Xu, L.-H., Kim, C.-J. \& Jiang, C.-L. (2004). Nocardiopsis salina sp. nov., a novel halophilic actinomycete isolated from saline soil in China. Int J Syst Evol Microbiol 54, 1805-1809.

Li, W.-J., Chen, H.-H., Kim, C.-J., Park, D.-J., Tang, S.-K., Lee, J.-C., Xu, L.-H. \& Jiang, C.-L. (2005a). Microbacterium halotolerans sp. nov., isolated from a saline soil in the west of China. Int J Syst Evol Microbiol 55, 67-70.

Li, W.-J., Zhang, Y.-G., Zhang, Y.-Q., Tang, S.-K., Xu, P., Xu, L.-H. \& Jiang, C.-L. (2005b). Streptomyces sodiiphilus sp. nov., a novel alkaliphilic actinomycete. Int J Syst Evol Microbiol 55, 1329-1333.

Li, W.-J., Schumann, P., Zhang, Y.-Q., Chen, G.-Z., Tian, X.-P., Xu, L.-H., Stackebrandt, E. \& Jiang, C.-L. (2005c). Marinococcus halotolerans sp. nov., isolated from Qinghai, north-west China. Int I Syst Evol Microbiol 55, 1801-1804.

Li, W.-J., Schumann, P., Zhang, Y.-Q., Xu, P., Chen, G.-Z., Xu, L.-H., Stackebrandt, E. \& Jiang, C.-L. (2005d). Proposal of Yaniaceae fam. nov. and Yania flava sp. nov. and emended description of the genus Yania. Int J Syst Evol Microbiol 55, 1933-1938.

Li, W.-J., Kroppenstedt, R. M., Wang, D., Tang, S.-K., Lee, J.-C., Park, D.-J., Kim, C.-J., Xu, L.-H. \& Jiang, C.-L. (2006). Five novel species of genus Nocardiopsis isolated from hypersaline soils and emended description of Nocardiopsis salina. Int J Syst Evol Microbiol 56, 1089-1096.

Mandel, M. \& Marmur, J. (1968). Use of ultraviolet absorbancetemperature profile for determining the guanine plus cytosine content of DNA. Methods Enzymol 12B, 195-206.

Meyer, J. (1976). Nocardiopsis, a new genus of the order Actinomycetales. Int J Syst Bacteriol 26, 487-493.

Meyer, J. (1994). The genus Nocardiopsis Meyer 1976. In Bergey's Manual of Determinative Bacteriology, 9th edn, pp. 2562-2568. Edited by J. G. Holt, N. R. Krieg, P. H. A. Sneath, J. T. Staley \& S. T. Williams. Baltimore: Williams \& Wilkins.

Minnikin, D. E., O'Donnell, A. G., Goodfellow, M., Alderson, G., Athalye, M., Schaal, A. \& Parlett, J. H. (1984). An integrated procedure for the extraction of bacterial isoprenoid quinones and polar lipids. J Microbiol Methods 2, 233-241.

Peltola, J. S. P., Andersson, M. A., Kämpfer, P., Auling, G., Kroppenstedt, R. M., Busse, H.-J., Salkinoja-Salonen, M. S. \& Rainey, F. A. (2001). Isolation of toxigenic Nocardiopsis strains from indoor environments and description of two new Nocardiopsis species, N. exhalans sp. nov. and N. umidischolae sp. nov. Appl Environ Microbiol 67, 4293-4304.

Sabry, S. A., Ghanem, N. B., Abu-Ella, G. A., Schumann, P., Stackebrandt, E. \& Kroppenstedt, R. M. (2004). Nocardiopsis aegyptia sp. nov., isolated from marine sediment. Int J Syst Evol Microbiol 54, 453-456.

Saitou, N. \& Nei, M. (1987). The neighbor-joining method: a new method for reconstructing phylogenetic trees. Mol Biol Evol 4, 406-425.

Schippers, A., Bosecker, K., Willscher, S., Spröer, C., Schumann, P. \& Kroppenstedt, R. M. (2002). Nocardiopsis metallicus sp. nov., a metal-leaching actinomycete isolated from an alkaline slag dump. Int J Syst Evol Microbiol 52, 2291-2295.

Schumann, P., Cui, X., Stackebrandt, E., Kroppenstedt, R. M., Xu, L. \& Jiang, C. (2004). Jonesia quinghaiensis sp. nov., a new member of the suborder Micrococcineae. Int J Syst Evol Microbiol 54, 2181-2184.

Shirling, E. B. \& Gottlieb, D. (1966). Methods for characterization of Streptomyces species. Int J Syst Bacteriol 16, 313-340.

Staneck, J. L. \& Roberts, G. D. (1974). Simplified approach to identification of aerobic actinomycetes by thin-layer chromatography. Appl Microbiol 28, 226-231.

Thompson, J. D., Gibson, T. J., Plewniak, F., Jeanmougin, F. \& Higgins, D. G. (1997). The CLUSTAL_X windows interface: flexible 
strategies for multiple sequence alignment aided by quality analysis tools. Nucleic Acids Res 25, 4876-4882.

Wayne, L. G., Brenner, D. J., Colwell, R. R., Grimont, P. A. D., Kandler, O., Krichevsky, M. I., Moore, L. H., Moore, W. E. C., Murray, R. G. E. \& other authors (1987). International Committee on Systematic Bacteriology. Report of the ad hoc committee on reconciliation of approaches to bacterial systematics. Int J Syst Bacteriol 37, 463-464.

Williams, S. T., Goodfellow, M. \& Alderson, G. (1989). Genus Streptomyces Waksman and Henrici 1943, 339 $9^{\mathrm{AL}}$. In Bergey's Manual of Systematic Bacteriology, vol. 4, pp. 2452-2492. Edited by S. T. Williams, M. E. Sharpe \& J. G. Holt. Baltimore: Williams \& Wilkins.

Yassin, A. F., Galinski, E. A., Wohlfarth, A., Jahnke, K.-D., Schaal, K. P. \& Trüper, H. G. (1993). A new actinomycete species, Nocardiopsis lucentensis sp. nov. Int J Syst Bacteriol 43, 266-271.
Yassin, A. F., Rainey, F. A., Burghardt, J., Gierth, D., Ungerechts, J., Lux, I., Seifert, P., Bal, C. \& Schaal, K. P. (1997). Description of Nocardiopsis synnemataformans sp. nov., elevation of Nocardiopsis alba subsp. prasina to Nocardiopsis prasina comb. nov., and designation of Nocardiopsis antarctica and Nocardiopsis alborubida as later subjective synonyms of Nocardiopsis dassonvillei. Int J Syst Bacteriol 47, 983-988.

Zhang, Y.-O., Schumann, P., Li, W.-J., Chen, G.-Z., Tian, X.-P., Stackebrandt, E., Xu, L.-H. \& Jiang, C.-L. (2005). Isoptericola halotolerans sp. nov., a novel actinobacterium isolated from saline soil from Qinghai Province, north-west China. Int J Syst Evol Microbiol 55, 1867-1870.

Zhang, Y.-O., Schumann, P., Yu, L.-Y., Liu, H.-Y., Zhang, Y.-O., Xu, L.-H., Stackebrandt, E., Jiang, C.-L. \& Li, W.-J. (2007). Zhihengliuella halotolerans gen. nov., sp. nov., a novel member of the family Micrococcaceae. Int J Syst Evol Microbiol 57, 1018-1023. 